Supporting Information for:

\title{
Reactivity of a Nickel Sulfide with Carbon Monoxide and Nitric Oxide
}

\author{
Nathaniel J. Hartmann, Guang Wu, and Trevor W. Hayton* \\ Department of Chemistry and Biochemistry, University of California Santa Barbara, \\ Santa Barbara CA 93106 \\ *To whom correspondence should be addressed. Email: hayton@chem.ucsb.edu
}


Table of Contents

\begin{tabular}{lr}
\hline Experimental Details & $\mathrm{S} 3$ \\
NMR Spectra & $\mathrm{S} 10$ \\
X-ray Crystallographic Data & $\mathrm{S} 17$ \\
IR Spectra & $\mathrm{S} 20$ \\
UV-Vis Spectra & $\mathrm{S} 22$ \\
References & $\mathrm{S} 23$ \\
\hline
\end{tabular}




\section{Experimental}

General. All reactions and subsequent manipulations were performed under anaerobic and anhydrous conditions under an atmosphere of nitrogen. Hexanes, diethyl ether $\left(\mathrm{Et}_{2} \mathrm{O}\right)$, and toluene were dried using a Vacuum Atmospheres DRI-SOLV Solvent Purification system and stored over $3 \AA$ sieves for $24 \mathrm{~h}$ prior to use. Acetonitrile, benzene$d_{6}$, pentane, and $\mathrm{C}_{8} \mathrm{H}_{18}$ (isooctane) were dried over $3 \AA$ molecular sieves for $24 \mathrm{~h}$ prior to use. Acetone was dried by distillation (twice) from $\mathrm{B}_{2} \mathrm{O}_{3}$. $\left[\mathrm{K}\left(18\right.\right.$-crown-6)][L $\left.{ }^{\mathrm{tBu}} \mathrm{Ni}(\mathrm{S})\right]$ and $[\mathrm{PNP}]\left[\mathrm{NO}_{2}\right]$ were synthesized according to the previously reported procedures. ${ }^{1,2}$ Nitric oxide (NO) and carbon monoxide (CO) were supplied by Praxair and used as received. All other reagents were purchased from commercial suppliers and used as received.

${ }^{1} \mathrm{H}$ and ${ }^{13} \mathrm{C}\left\{{ }^{1} \mathrm{H}\right\}$ NMR spectra were recorded on a Agilent Technologies $400-\mathrm{MR}$ DD2 $400 \mathrm{MHz}$ spectrometer or a Varian UNITY INOVA $500 \mathrm{MHz}$ spectrometer. ${ }^{1} \mathrm{H}$ and ${ }^{13} \mathrm{C}\left\{{ }^{1} \mathrm{H}\right\}$ NMR spectra were referenced to external $\mathrm{SiMe}_{4}$ using the residual protio solvent peaks as internal standards. IR spectra were recorded on a Nicolet 6700 FT-IR spectrometer. Electronic absorption spectra were recorded on a Shimadzu UV3600 UVNIR Spectrometer. Elemental analyses were performed by the Micro-Mass Facility at the University of California, Berkeley.

\section{Synthesis of $[\mathrm{K}(18-\mathrm{crown}-6)]\left[\mathrm{L}^{\mathrm{tBu}} \mathrm{Ni}\left(C, S: \eta^{2}-\mathrm{C}(\mathrm{O}) \mathrm{S}\right)\right]$ (1) via reaction of $[\mathrm{K}(18-$} crown-6)][L $\left.{ }^{\mathrm{tBu}} \mathbf{N i ( S )}\right]$ with CO. A $50 \mathrm{~mL}$ Schlenk flask, equipped with a Teflon rotoflow valve, was charged with a dark brown solution of $\left[\mathrm{K}(18\right.$-crown-6) $]\left[\mathrm{L}^{\mathrm{tBu}} \mathrm{Ni}(\mathrm{S})\right](35.0 \mathrm{mg}$, $0.0391 \mathrm{mmol})$ in toluene $(2 \mathrm{~mL})$. The headspace was then evacuated and filled with $\mathrm{CO}$ gas (1 atm). After addition of $\mathrm{CO}$, the solution rapidly changed from dark brown to pale 
yellow. After stirring the solution for one minute, the headspace was evacuated and replaced with $\mathrm{N}_{2}$. The Schlenk flask was then transferred into a glovebox, and the reaction mixture was filtered through a Celite column supported on glass wool $(0.5 \mathrm{~cm} \times$ $2 \mathrm{~cm}$ ). The filtrate was then concentrated to ca. $0.25 \mathrm{~mL}$ in vacuo. Addition of isooctane $(1 \mathrm{~mL})$ to this solution and subsequent storage at $-25{ }^{\circ} \mathrm{C}$ for $48 \mathrm{~h}$ resulted in the deposition of orange plates of $\left[\mathrm{K}\left(18\right.\right.$-crown-6)][ $\left.\mathrm{L}^{\mathrm{tBu}} \mathrm{Ni}\left(C, S: \eta^{2}-\mathrm{C}(\mathrm{O}) \mathrm{S}\right)\right](\mathbf{1})$, which were isolated by decanting off the supernatant ( $31.8 \mathrm{mg}, 88 \%$ yield). Crystals suitable for Xray diffraction were grown from concentrated solution of 1 in a $\sim 1: 1$ mixture of hexanes and benzene that was stored at $-25{ }^{\circ} \mathrm{C}$ for $24 \mathrm{~h}$. Anal. Calcd for: $\mathrm{C}_{48} \mathrm{H}_{77} \mathrm{KN}_{2} \mathrm{NiO}_{7} \mathrm{~S}$ : C, 62.39; H, 8.40; N, 3.03. Found: C, 62.02; H, 8.10; N, 2.95. ${ }^{1} \mathrm{H}$ NMR $\left(400 \mathrm{MHz}, 25^{\circ} \mathrm{C}\right.$, benzene- $\left.d_{6}\right): \delta$ 7.25-6.97 (m, 6H, Ar-H, dipp), $5.48(\mathrm{~s}, 1 \mathrm{H}, \gamma-\mathbf{H}), 4.24\left(\mathrm{sept},{ }^{3} J_{\mathrm{HH}},=6.7\right.$ $\left.\mathrm{Hz}, 2 \mathrm{H}, \mathrm{CH}\left(\mathrm{CH}_{3}\right)_{2}\right), 4.19$ (sept, $\left.{ }^{3} J_{\mathrm{HH}},=6.7 \mathrm{~Hz}, 2 \mathrm{H}, \mathrm{CH}\left(\mathrm{CH}_{3}\right)_{2}\right), 2.99$ (s, 24H, 18-crown6), $2.01\left(\mathrm{~d},{ }^{3} J_{\mathrm{HH}}=6.8 \mathrm{~Hz}, 6 \mathrm{H}, \mathrm{CH}\left(\mathrm{CH}_{3}\right)_{2}\right), 1.80\left(\mathrm{~d},{ }^{3} J_{\mathrm{HH}}=6.8 \mathrm{~Hz}, 6 \mathrm{H}, \mathrm{CH}\left(\mathrm{CH}_{3}\right)_{2}\right), 1.55$ (overlapping doublets, 12H, $\left.\mathrm{CH}\left(\mathrm{CH}_{3}\right)_{2}\right), 1.43\left(\mathrm{~s}, 9 \mathrm{H}, \mathrm{C}\left(\mathrm{CH}_{3}\right)_{3}\right), 1.41\left(\mathrm{~s}, 9 \mathrm{H}, \mathrm{C}\left(\mathrm{CH}_{3}\right)_{3}\right)$. ${ }^{13} \mathrm{C}$ NMR $\left(125 \mathrm{MHz}, 25{ }^{\circ} \mathrm{C}\right.$, benzene- $\left.d_{6}\right): \delta 214.72(\mathrm{SC}(\mathrm{O})), 166.17$ (Ar-C), 165.94 (ArC), 153.53 (Ar-C), 152.78 (Ar-C), 141.05 (Ar-C), 140.94 (Ar-C), 122.30 - 121.55 (Ar-C), $95.20\left(\gamma\right.$-C), 69.43 (18-crown-6), $\left.42.88\left(\mathbf{C}\left(\mathrm{CH}_{3}\right)_{3}\right), 42.44\left(\mathbf{C}\left(\mathrm{CH}_{3}\right)_{3}\right), 33.87\left(\mathrm{C}_{(\mathbf{C H}}\right)_{3}\right)$, $33.48\left(\mathrm{C}\left(\mathrm{CH}_{3}\right)_{3}\right), 28.19\left(\mathrm{CH}\left(\mathrm{CH}_{3}\right)_{2}\right), 27.85\left(\mathrm{CH}\left(\mathrm{CH}_{3}\right)_{2}\right), 25.79\left(\mathrm{CH}\left(\mathrm{CH}_{3}\right)_{2}\right), 24.36$ $\left(\mathrm{CH}\left(\mathrm{CH}_{3}\right)_{2}\right), 24.23\left(\mathrm{CH}\left(\mathrm{CH}_{3}\right)_{2}\right), 23.85\left(\mathbf{C H}\left(\mathrm{CH}_{3}\right)_{2}\right)$. IR $\left(\mathrm{KBr}\right.$ Pellet, $\left.\mathrm{cm}^{-1}\right): 1676\left(\mathrm{~s}, v_{\mathrm{CO}}\right)$, 1624 (br w), 1535 (m), 1510 (s), 1473 (m), 1450 (m), 1444 (m), 1409 (s), 1385 (m), 1365 (m), $1352(\mathrm{~s}), 1321(\mathrm{~s}), 1286(\mathrm{w}), 1250(\mathrm{w}), 1221(\mathrm{w}), 1192(\mathrm{w}), 1160(\mathrm{w}), 1111(\mathrm{~s})$, 1057 (w), 964 (s), 937 (w), 896 (w), 839 (m), 804 (w), 776 (m), 758 (m), 642 (m), 579 (w), $530(w)$. 


\section{Synthesis of $\left[\mathrm{L}^{\mathrm{tBu}} \mathrm{Ni}(\mathrm{NO})\right](2)$ and $[\mathrm{K}(18-\mathrm{crown}-6)][S S N O]$ (3) via reaction of}

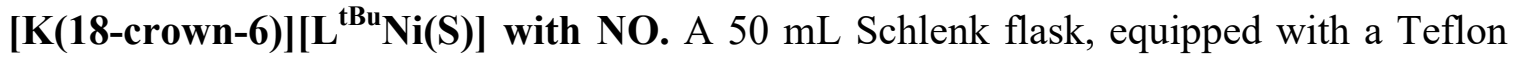
rotoflow valve, was charged with a dark brown solution of $\left[\mathrm{K}\left(18\right.\right.$-crown-6)][L $\left.{ }^{\mathrm{tBu}} \mathrm{Ni}(\mathrm{S})\right]$ (53.0 $\mathrm{mg}, 0.0592 \mathrm{mmol})$ in toluene $(2 \mathrm{~mL})$. The headspace was then evacuated and filled with NO gas (1 atm). After addition of NO, the solution rapidly changed from dark brown to brown-green. After stirring the solution for one minute, the headspace was evacuated and replaced with $\mathrm{N}_{2}$. The Schlenk flask was then transferred to a glovebox, and the volatiles were removed in vacuo to give a pale brown solid. This solid was then washed with pentane $(3 \times 1 \mathrm{~mL})$ and the washings were collected and filtered through a Celite column supported on glass wool $(0.5 \mathrm{~cm} \times 2 \mathrm{~cm})$ to give a pale green solution, while leaving a yellow-orange solid on the Celite column. The volatiles were then removed from the green solution in vacuo to give a green-brown solid. The solid was extracted into $\mathrm{Et}_{2} \mathrm{O}(0.5 \mathrm{~mL})$ and transferred to a $5 \mathrm{~mL}$ vial. This vial was placed inside a $20 \mathrm{~mL}$ scintillation vial. Toluene $(2 \mathrm{~mL})$ was then added to the outer vial. Storage of this two vial system at $-25^{\circ} \mathrm{C}$ for $72 \mathrm{~h}$ resulted in the deposition of dichroic plates that appear to be blue or orange depending upon their orientation relative to a light source. This solid was isolated by decanting off the supernatant $(28.0 \mathrm{mg}, 80 \%$ yield $)$. Separately, the insoluble yellow-orange solid was extracted into dichloromethane $(2 \mathrm{~mL})$ to give an orange solution. This solution was concentrated to ca. $0.5 \mathrm{~mL}$ in vacuo, filtered through a Celite column supported on glass wool $(0.5 \mathrm{~cm} \times 2 \mathrm{~cm})$, and transferred to a $5 \mathrm{~mL}$ vial. This vial was placed inside a $20 \mathrm{~mL}$ scintillation vial. Pentane $(2 \mathrm{~mL})$ was then added to the outer vial. Storage of this two vial system at $-25^{\circ} \mathrm{C}$ for $72 \mathrm{~h}$ resulted in the deposition of orange plates of $[\mathrm{K}(18$-crown-6)][SSNO] (3), which were isolated by 
decanting off the supernatant ( $10.1 \mathrm{mg}, 86 \%$ yield based on sulfur). Anal. Calcd for 2 : $\mathrm{C}_{35} \mathrm{H}_{53} \mathrm{~N}_{3} \mathrm{NiO}$ : C, 71.19; H, 9.05; N, 7.12. Found: C, 70.82; H, 9.02; N, 7.09. ${ }^{1} \mathrm{H}$ NMR (400 MHz, $25^{\circ} \mathrm{C}$, benzene- $\left.d_{6}\right): \delta$ 7.21-7.11 (m, 6H, Ar-H, dipp), $4.91(\mathrm{~s}, 1 \mathrm{H}, \gamma-\mathbf{H}), 3.90$ (sept, $\left.{ }^{3} J_{\mathrm{HH}},=6.7 \mathrm{~Hz}, 4 \mathrm{H}, \mathrm{CH}\left(\mathrm{CH}_{3}\right)_{2}\right), 1.67\left(\mathrm{~d},{ }^{3} J_{\mathrm{HH}}=6.8 \mathrm{~Hz}, 12 \mathrm{H}, \mathrm{CH}\left(\mathrm{CH}_{3}\right)_{2}\right), 1.42(\mathrm{~d}$, $\left.{ }^{3} J_{\mathrm{HH}},=6.8 \mathrm{~Hz}, 12 \mathrm{H}, \mathrm{CH}\left(\mathrm{CH}_{3}\right)_{2}\right) 1.10\left(\mathrm{~s}, 18 \mathrm{H}, \mathrm{C}\left(\mathrm{CH}_{3}\right)_{3}\right) \cdot{ }^{13} \mathrm{C} \mathrm{NMR}\left(125 \mathrm{MHz}, 25{ }^{\circ} \mathrm{C}\right.$, benzene- $\left.d_{6}\right): \delta 169.59(\mathrm{Ar}-\mathrm{C}), 152.66(\mathrm{Ar}-\mathrm{C}), 141.66(\mathrm{Ar}-\mathrm{C}), 126.00(\mathrm{Ar}-\mathrm{C}), 123.66(\mathrm{Ar}-$ C), $93.74 \quad(\gamma-\mathbf{C}) \quad 43.70 \quad\left(\mathbf{C}\left(\mathrm{CH}_{3}\right)_{3}\right), \quad 33.32 \quad\left(\mathrm{C}_{\left.\left(\mathbf{C H}_{3}\right)_{3}\right),} 29.16 \quad\left(\mathrm{CH}\left(\mathrm{CH}_{3}\right)_{2}\right), \quad 25.83\right.$ $\left(\mathrm{CH}\left(\mathrm{CH}_{3}\right)_{2}\right), 23.56\left(\mathrm{CH}\left(\mathrm{CH}_{3}\right)_{2}\right)$. IR (KBr Pellet, $\left.\mathrm{cm}^{-1}\right): 1784$ (s, v $\left.v_{\mathrm{NO}}\right), 1647$ (br w), 1537 (m), 1508 (s), 1464 (s), 1446 (s), 1435 (s), 1387 (s), 1365 (s), 1321 (s), 1259 (m), 1252 (m), $1221(\mathrm{~s}), 1196(\mathrm{~m}), 1180(\mathrm{~m}), 1157$ (m), $1040(\mathrm{~m}), 1101(\mathrm{~s}), 1055(\mathrm{~m}), 1032(\mathrm{~m})$, $966(w), 931(w), 897(w), 820(m), 802(m), 779(m), 756(m), 723(w), 687(w), 615$ (w), $532(\mathrm{w}), 476(\mathrm{w}), 455(\mathrm{w}), 436(\mathrm{w})$. IR $\left(\mathrm{C}_{6} \mathrm{H}_{6}, \mathrm{~cm}^{-1}\right)$ : 1784 (s, v $\left.v_{\mathrm{NO}}\right)$. Anal. Calcd for 3: $\mathrm{C}_{12} \mathrm{H}_{24} \mathrm{KNO}_{7} \mathrm{~S}_{2}: \mathrm{C}, 36.25 ; \mathrm{H}, 6.08 ; \mathrm{N}, 3.52$. Found: Trial 1: C, 38.40; H, 6.33; N, 3.21; Trial 2: $\mathrm{C}, 37.93 ; \mathrm{H}, 6.30 ; \mathrm{N}, 3.34$. The high carbon percentage is attributed to the presence of a small amount of free 18-crown- 6 , which could not be separated from $\mathbf{3}$ by crystallization. ${ }^{1} \mathrm{H}$ NMR $\left(400 \mathrm{MHz}, 25^{\circ} \mathrm{C}\right.$, benzene- $\left.d_{6}\right): \delta 3.20$ (s, 24H, 18-crown-6). IR (KBr Pellet, $\mathrm{cm}^{-1}$ ): 1969 (w), 1778 (w), 1639 (br w), 1473 (m), 1456 (m), 1435 (w), 1385 (m), $1352(\mathrm{~s}), 1313\left(\mathrm{~m}, v_{\mathrm{NO}}\right), 1282(\mathrm{~m}), 1252(\mathrm{~m}), 1223(\mathrm{~m}), 1107(\mathrm{~s}), 1030(\mathrm{~m}), 962(\mathrm{~s})$, 860 (w), 837 (m), 804 (br m), 690 (w), 669 (m), 553 (m), 532 (w), 492 (br m), 409 (w). UV-vis (MeCN, $\left.1.0 \mathrm{mM}, 25^{\circ} \mathrm{C}\right): 443 \mathrm{~nm}\left(\varepsilon=930 \mathrm{~L} \cdot \mathrm{mol}^{-1} \cdot \mathrm{cm}^{-1}\right)$.

Reaction of [K(18-crown-6)][ $\left.\mathrm{L}^{\mathrm{tBu}} \mathrm{Ni}(\mathrm{S})\right]$ with one equiv of NO. A $50 \mathrm{~mL}$ Schlenk flask, equipped with a septum, was charged with a dark brown solution of [K(18-crown6)][ $\left.\mathrm{L}^{\mathrm{tBu}} \mathrm{Ni}(\mathrm{S})\right](19 \mathrm{mg}, 0.021 \mathrm{mmol})$ in toluene $(2 \mathrm{~mL})$ and cooled to $0{ }^{\circ} \mathrm{C}$. Under an 
atmosphere of $\mathrm{N}_{2}$, NO gas $(0.52 \mathrm{~mL}, 0.021 \mathrm{mmol})$ was slowly bubbled into the solution using an airtight, volumetric syringe. Upon addition of NO, the solution rapidly changed from dark brown to pale brown. After stirring for $10 \mathrm{~min}$, the volatiles were removed in vacuo, and the flask was transferred to the glove box. The reaction mixture was dissolved in $\mathrm{C}_{6} \mathrm{D}_{6}(0.5 \mathrm{~mL})$ to give a green-brown solution and a ${ }^{1} \mathrm{H}$ NMR spectrum of this sample was recorded. This spectrum revealed that presence of a mixture of complex 2 and $\left[\mathrm{K}\left(18\right.\right.$-crown-6)][ $\left.\mathrm{L}^{\mathrm{tBu}} \mathrm{Ni}(\mathrm{S})\right](\mathbf{I})$ in a $\sim 2: 1$ ratio, along with a small amount (less than 5\%) of an unidentified diamagnetic product (Figure S6-S7). ${ }^{1} \mathrm{H}$ NMR $\left(400 \mathrm{MHz}, 25{ }^{\circ} \mathrm{C}\right.$, benzene- $\left.d_{6}\right): \delta 28.38(\mathbf{I}, \mathrm{s}, 4 \mathrm{H}, \operatorname{Ar}-m \mathbf{H}), 26.26\left(\mathbf{I}, \mathrm{s}, \mathrm{CH}\left(\mathrm{CH}_{3}\right)_{2}\right), 16.07(\mathbf{I}, 12 \mathrm{H}$, $\left.\mathrm{CH}\left(\mathrm{CH}_{3}\right)_{2}\right), 7.21-7.11(\mathbf{2}, \mathrm{m}, 6 \mathrm{H}, \mathrm{Ar}-\mathbf{H}, \mathrm{dipp}), 6.71\left(\mathbf{I}, 12 \mathrm{H}, \mathrm{CH}\left(\mathrm{CH}_{3}\right)_{2}\right), 4.91(\mathbf{2}, \mathrm{s}, 1 \mathrm{H}, \boldsymbol{\gamma}-$ H), $3.90\left(\mathbf{2}\right.$, sept, $\left.{ }^{3} J_{\mathrm{HH}},=6.7 \mathrm{~Hz}, 4 \mathrm{H}, \mathrm{CH}\left(\mathrm{CH}_{3}\right)_{2}\right), 2.73$ (18-crown-6), $1.67\left(\mathbf{2}, \mathrm{d},{ }^{3} J_{\mathrm{HH}},=\right.$ $\left.6.8 \mathrm{~Hz}, 12 \mathrm{H}, \mathrm{CH}\left(\mathrm{CH}_{3}\right)_{2}\right), 1.42\left(\mathbf{2}, \mathrm{d},{ }^{3} J_{\mathrm{HH}},=6.8 \mathrm{~Hz}, 12 \mathrm{H}, \mathrm{CH}\left(\mathrm{CH}_{3}\right)_{2}\right) 1.10(2, \mathrm{~s}, 18 \mathrm{H}$, $\left.\mathrm{C}\left(\mathrm{CH}_{3}\right)_{3}\right),-0.74\left(\mathbf{I}, 18 \mathrm{H}, \mathrm{C}\left(\mathrm{CH}_{3}\right)_{3}\right),-18.83(\mathbf{I}, 2 \mathrm{H}, \mathrm{Ar}-p \mathbf{H}) \mathrm{ppm}$.

Synthesis of $[\mathrm{PNP}][\mathrm{SSNO}]$ from $[\mathrm{PNP}]\left[\mathrm{NO}_{2}\right]$ and $\mathbf{S}_{\mathbf{8}}$. The synthesis of [PNP][SSNO] was performed according to the previously reported procedure with slight modifications. ${ }^{3}$ To a stirring suspension of $\mathrm{S}_{8}(117.5 \mathrm{mg}, 0.458 \mathrm{mmol})$ in acetone $(1 \mathrm{~mL})$ was added an acetone $(15 \mathrm{~mL})$ solution of $[\mathrm{PNP}]\left[\mathrm{NO}_{2}\right]\left(\mathrm{PNP}=\mathrm{Ph}_{3} \mathrm{PNPPh}_{3}\right)(1.068 \mathrm{~g}, 1.832 \mathrm{mmol})$. The reaction mixture was protected from light and allowed to stir $24 \mathrm{~h}$, whereupon the sulfur was consumed and the reaction mixture turned dark orange. The reaction mixture was then filtered through a Celite column supported on glass wool $(0.5 \mathrm{~cm} \times 2 \mathrm{~cm})$ to give a dark orange solution. Storage of this solution at $-25{ }^{\circ} \mathrm{C}$ for $48 \mathrm{~h}$ results in the deposition of dark orange blocks ( $306 \mathrm{mg}, 26 \%$ ) that were isolated by decanting off the supernatant. This product was identified as [PNP][SSNO] by comparison of its unit cell 
(Orthorhombic P; V = $3098 \AA^{3} ; \mathrm{a}=11.90 \AA, \mathrm{b}=15.55 \AA, \mathrm{c}=16.74 \AA, \alpha=90.00^{\circ}, \beta=$ $\left.90.00^{\circ}, \gamma=90.00^{\circ}\right)$ with the previously reported values, and by IR spectroscopy $\left(v_{\mathrm{NO}}=\right.$ $1350 \mathrm{~cm}^{-1}, \mathrm{KBr}$ mull). ${ }^{3}$

Synthesis of $[\mathrm{PNP}][\mathrm{SNO}]$ from [PNP][SSNO] and $\mathbf{P P h}_{3}$. The synthesis of [PNP][SNO] was performed according to a previously reported procedure with slight modifications. ${ }^{3}$ To a stirring solution of [PNP][SSNO] $(57.0 \mathrm{mg}, 0.0877 \mathrm{mmol})$ in acetone $(5 \mathrm{~mL})$ was added a solution of $\mathrm{PPh}_{3}(28.7 \mathrm{mg}, 0.1754 \mathrm{mmol})$ in acetone $(1 \mathrm{~mL})$. This mixture was protected from light and allowed to stir for $24 \mathrm{~h}$. After $24 \mathrm{~h}$, the reaction mixture was a pale green color. This solution was concentrated in vacuo to ca. $1 \mathrm{~mL}$, and filtered through a Celite column supported on glass wool $(0.5 \mathrm{~cm} \times 2 \mathrm{~cm})$ to give a pale green solution. This solution was then transferred to a $5 \mathrm{~mL}$ vial. This vial was placed inside a $20 \mathrm{~mL}$ scintillation vial. $\mathrm{Et}_{2} \mathrm{O}(2 \mathrm{~mL})$ was then added to the outer vial. Storage of this two vial system at $-25{ }^{\circ} \mathrm{C}$ for $24 \mathrm{~h}$ resulted in the deposition of white crystals of $\mathrm{Ph}_{3} \mathrm{P}=\mathrm{S}$ (identified by ${ }^{31} \mathrm{P}$ NMR spectroscopy, $\delta=42.29 \mathrm{ppm}$ ) ${ }^{4}$ which were isolated by decanting off the supernatant. The pale green supernatant was then filtered through a Celite column supported on glass wool $(0.5 \mathrm{~cm} \times 2 \mathrm{~cm})$ and concentrated in vacuo to ca. $0.25 \mathrm{~mL}$ and transferred into a $5 \mathrm{~mL}$ vial. This vial was placed inside a $20 \mathrm{~mL}$ scintillation vial. $\mathrm{Et}_{2} \mathrm{O}$ $\left(2 \mathrm{~mL}\right.$ ) was then added to the outer vial. Storage of this two vial system at $-25^{\circ} \mathrm{C}$ for 72 $\mathrm{h}$ resulted in the deposition of pale green blocks (34 mg, 63\%) which were isolated by decanting off the supernatant. This product was identified as [PNP][SNO] by UV-vis spectroscopy $\left(\lambda_{\max }=334 \mathrm{~nm}, 1.0 \mathrm{mM}\right.$ in $\left.\mathrm{MeCN}\right)$.

Reaction of [PNP][SNO] with excess NO. A quartz UV-vis cell equipped with a Teflon rotoflow valve was charged with an $\mathrm{MeCN}$ solution of [PNP][SNO] (4 mL, $1.0 \mathrm{mmol})$. A 
UV-vis spectrum of this solution was recorded, which revealed a strong absorbance at $334 \mathrm{~nm}$ (Figure S14). The headspace was then evacuated and filled with NO gas (1 atm). After addition of NO, the solution rapidly changed from pale green to orange. A UV-vis spectrum of the reaction mixture was re-recorded. This spectrum revealed the complete consumption of the band assigned to [PNP] $[\mathrm{SNO}]$, and the appearance of a new feature at $445 \mathrm{~nm}$ that is attributed to the presence of [PNP][SSNO] (Figure S14). ${ }^{3}$ 


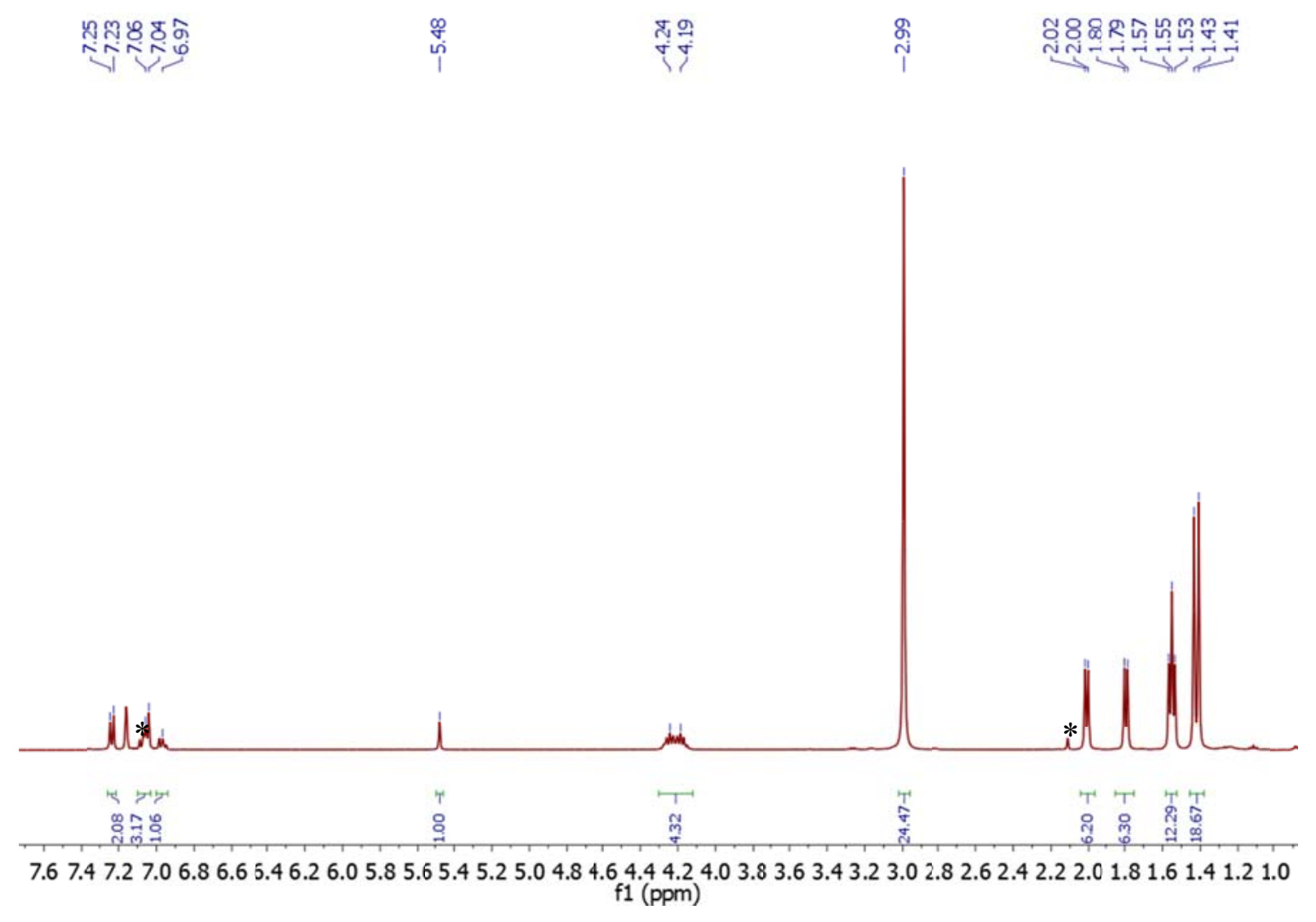

Figure S1. ${ }^{1} \mathrm{H}$ NMR spectrum of $\left[\mathrm{K}(18\right.$-crown-6) $]\left[\mathrm{L}^{\mathrm{tBu}} \mathrm{Ni}\left(C, S: \eta^{2}-\mathrm{C}(\mathrm{O}) \mathrm{S}\right)\right](\mathbf{1})$ in benzene$d_{6 .}(*)$ indicates the presence of toluene. 


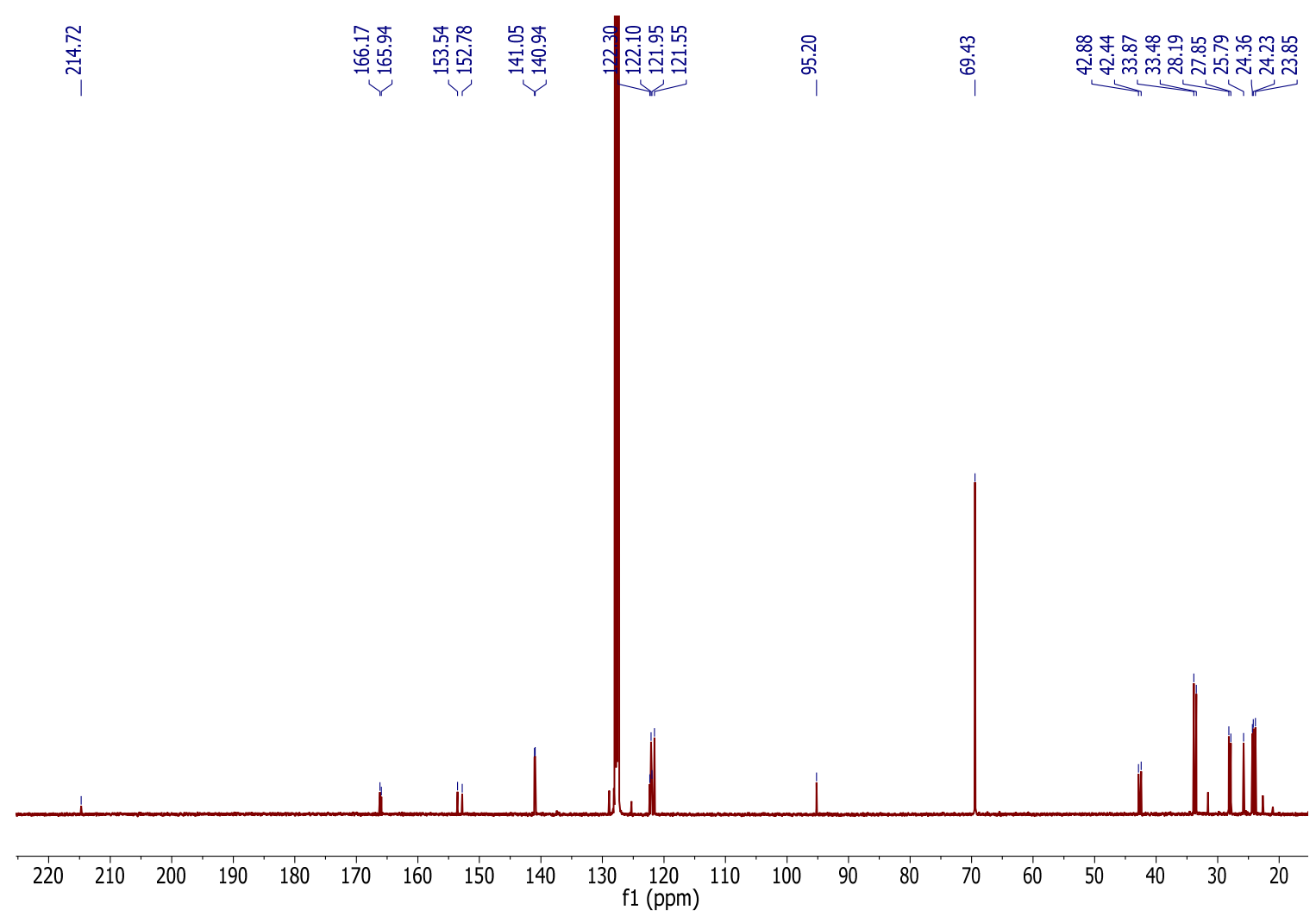

Figure S2. ${ }^{13} \mathrm{C}$ NMR spectrum of $\left[\mathrm{K}(18\right.$-crown-6) $]\left[\mathrm{L}^{\mathrm{tBu}} \mathrm{Ni}\left(C, S: \eta^{2}-\mathrm{C}(\mathrm{O}) \mathrm{S}\right)\right](\mathbf{1})$ in benzene- $d_{6}$. 

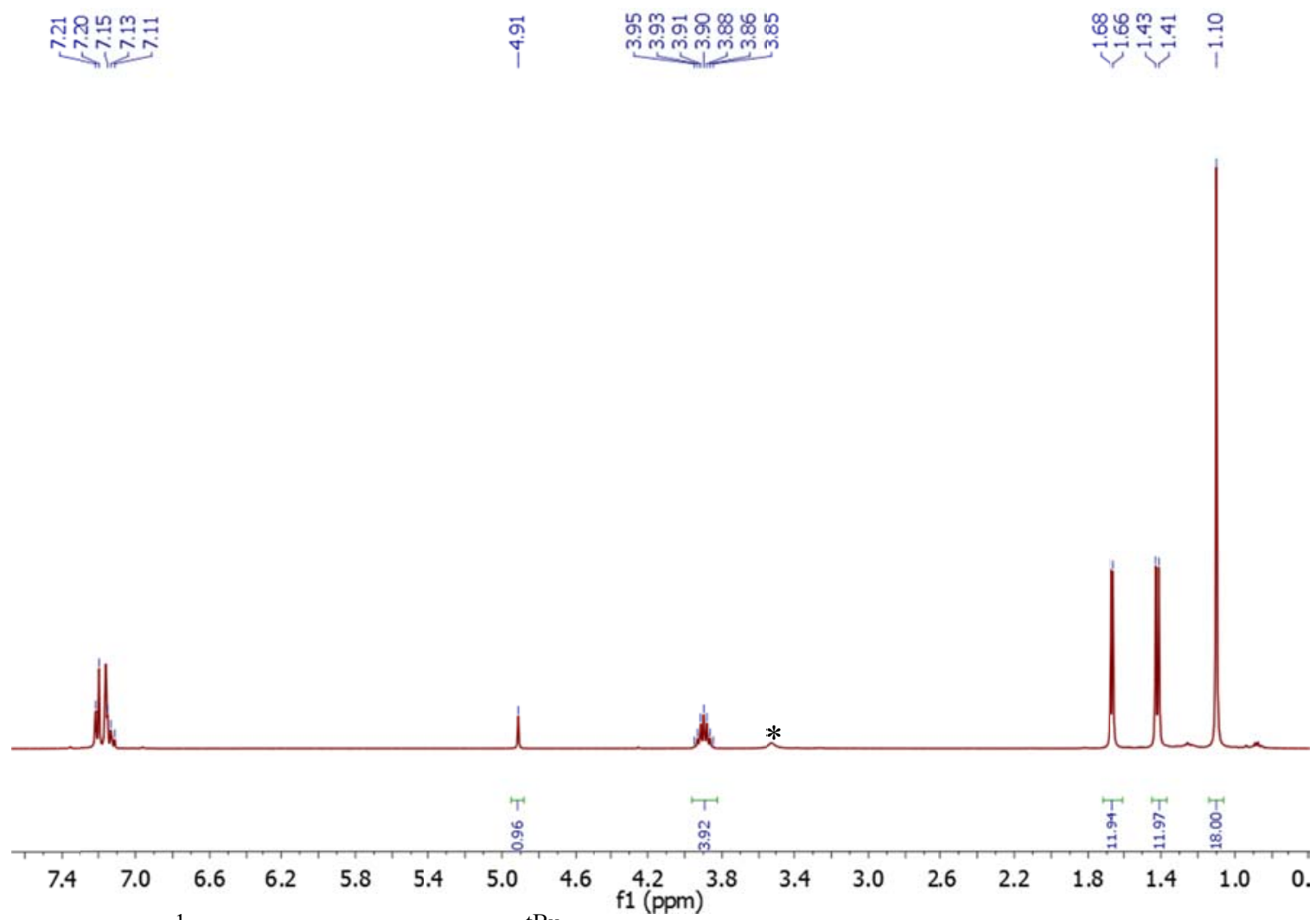

Figure S3. ${ }^{1} \mathrm{H}$ NMR spectrum of $\left[\mathrm{L}^{\mathrm{tBu}} \mathrm{Ni}(\mathrm{NO})\right](2)$ in benzene- $\left.d_{6} .{ }^{*}\right)$ indicates the presence of free 18-crown-6. 


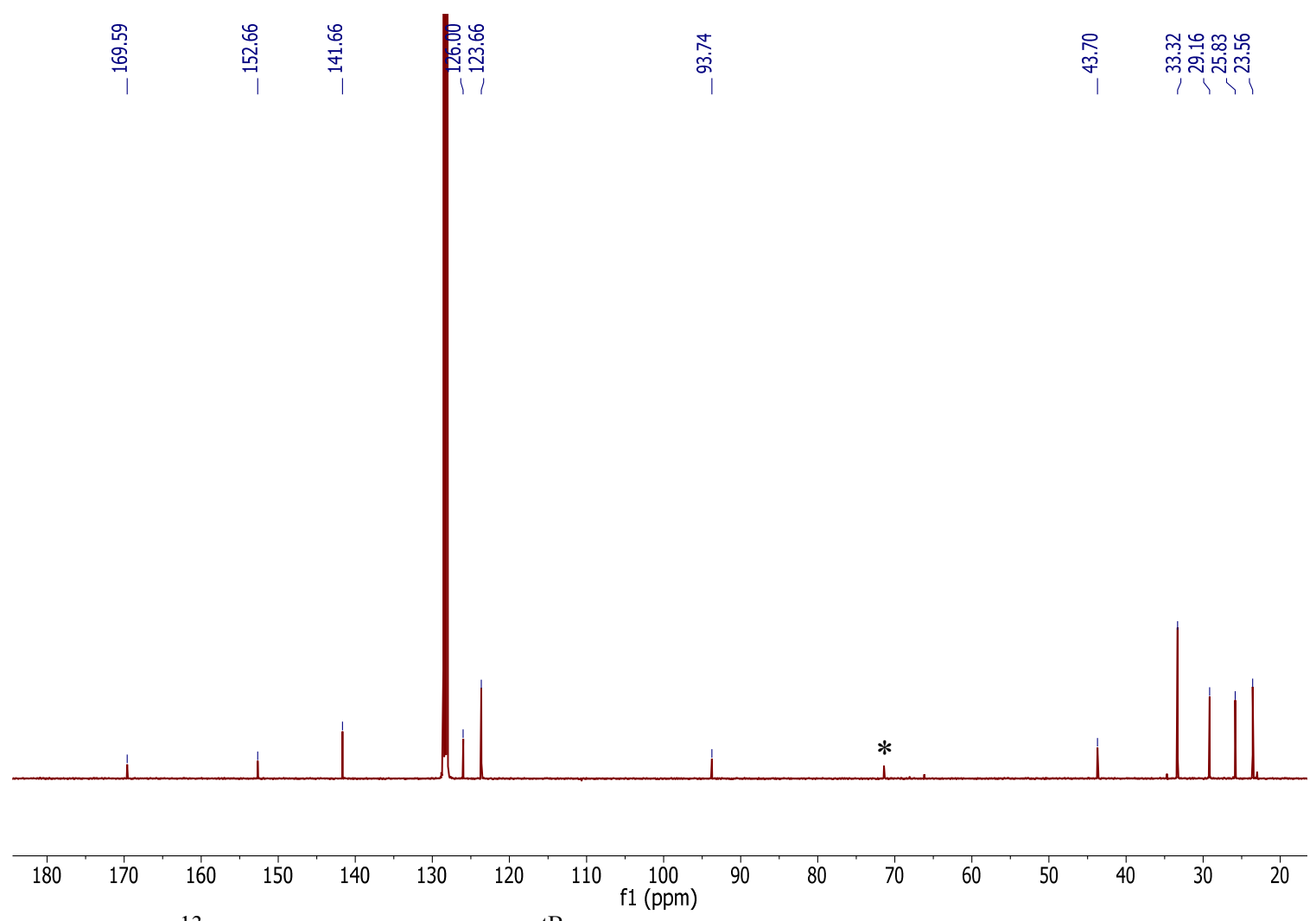

Figure S4. ${ }^{13} \mathrm{C}$ NMR spectrum of $\left[\mathrm{L}^{\mathrm{tBu}} \mathrm{Ni}(\mathrm{NO})\right](2)$ in benzene- $d_{6} \cdot(*)$ indicates the presence of free 18-crown-6. 


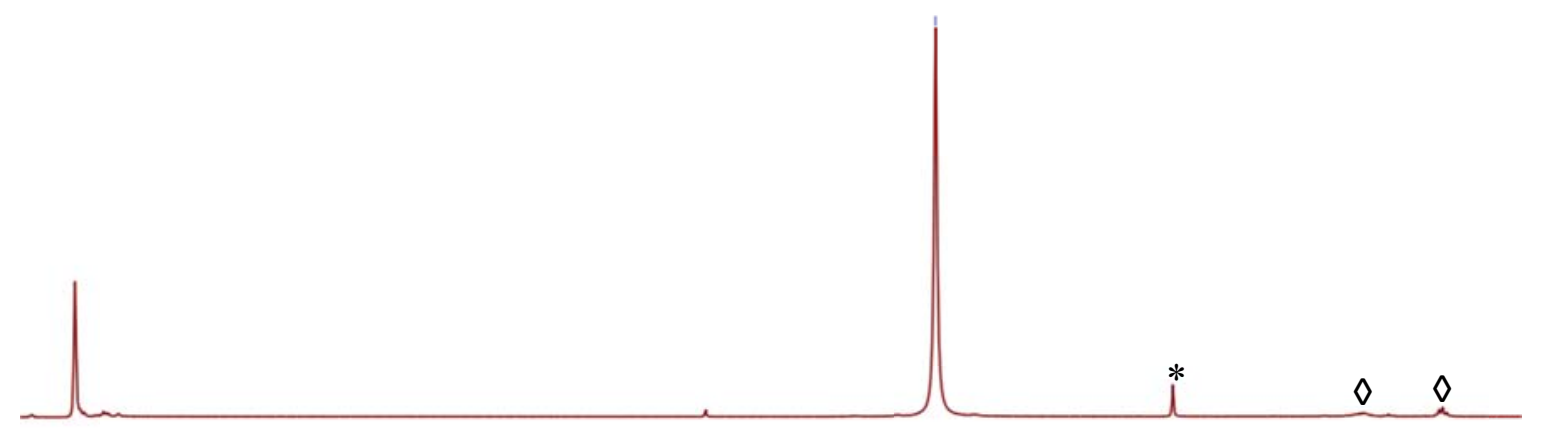

$\begin{array}{llllllllllllllllll}.4 & 7.0 & 6.6 & 6.2 & 5.8 & 5.4 & 5.0 & 4.6 & 4.2 & \begin{array}{c}3.8 \\ \mathrm{f} 1(\mathrm{ppm})\end{array} & 3.4 & 3.0 & 2.6 & 2.2 & 1.8 & 1.4 & 1.0 & 0.6\end{array}$

Figure S5. ${ }^{1} \mathrm{H}$ NMR spectrum of $\left[\mathrm{K}\left(18\right.\right.$-crown-6)][SSNO] (3) in $\mathrm{C}_{6} \mathrm{D}_{6}$. (*) indicates the presence of toluene and $(\diamond)$ indicates the presence of pentane. 


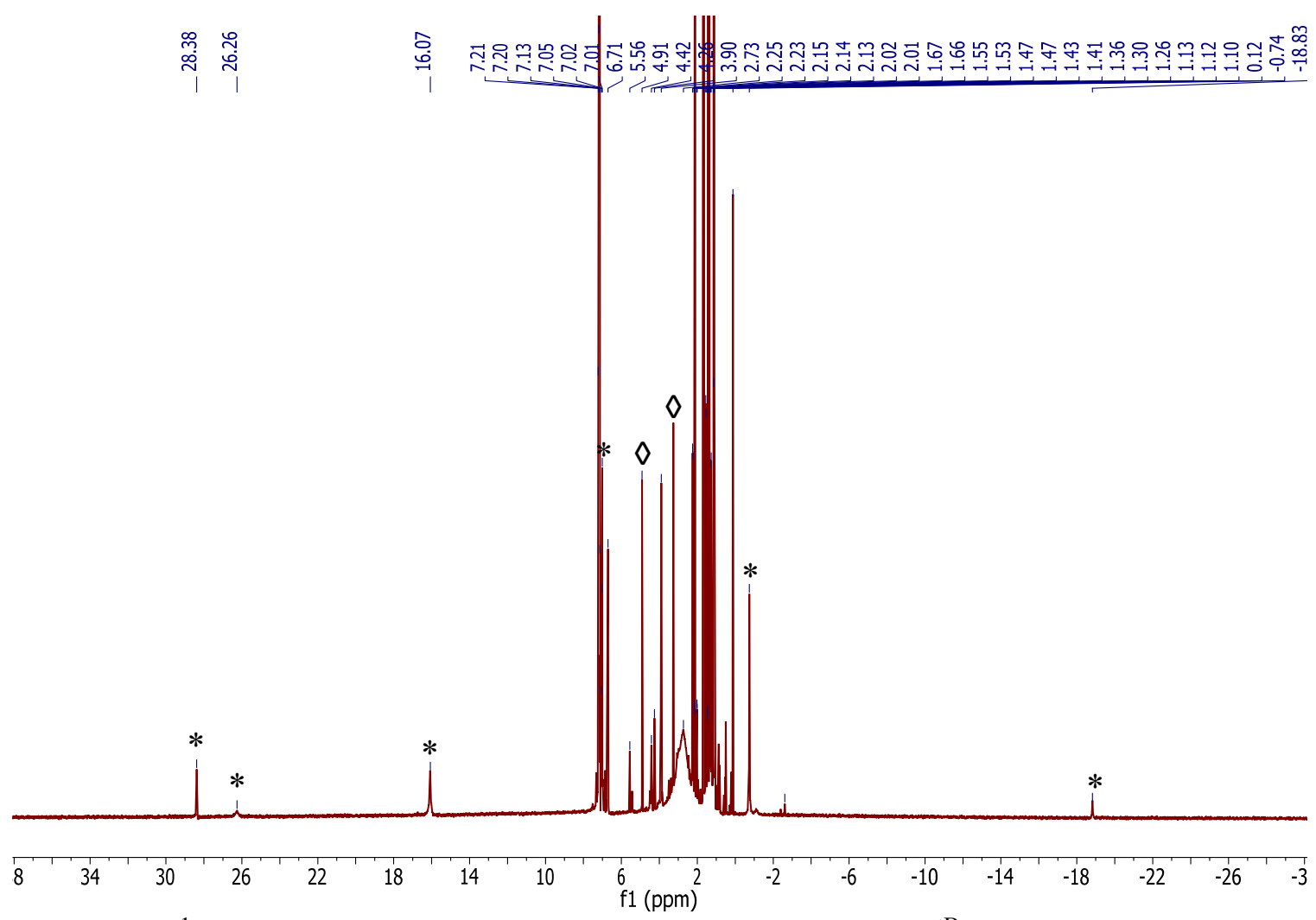

Figure S6. ${ }^{1} \mathrm{H}$ NMR spectrum of reaction of $\left[\mathrm{K}\left(18\right.\right.$-crown-6)][$\left[\mathrm{L}^{\mathrm{tBu}} \mathrm{Ni}(\mathrm{S})\right]$ with one equiv of NO in benzene- $d_{6} .\left(^{*}\right)$ indicates the presence of $\left[\mathrm{K}\left(18\right.\right.$-crown-6)][ $\left.\mathrm{L}^{\mathrm{tBu}} \mathrm{Ni}(\mathrm{S})\right]$ and $(\diamond)$ indicates the presence of $\left[\mathrm{L}^{\mathrm{tBu}} \mathrm{Ni}(\mathrm{NO})\right](2)$. 


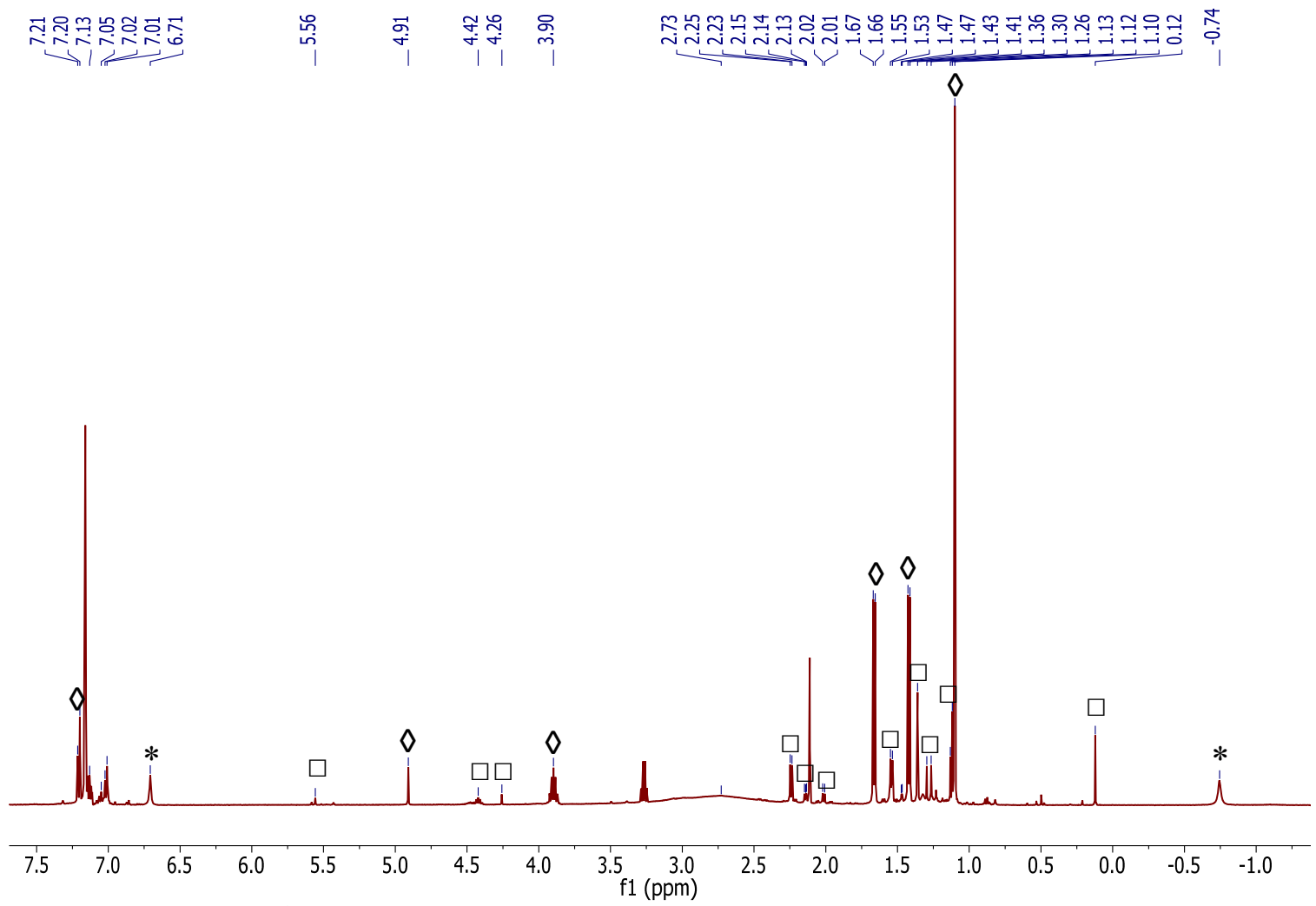

Figure S7. Partial ${ }^{1} \mathrm{H}$ NMR spectrum of reaction of $\left[\mathrm{K}\left(18\right.\right.$-crown-6)][ $\left.\mathrm{L}^{\mathrm{tBu}} \mathrm{Ni}(\mathrm{S})\right]$ with one equiv of $\mathrm{NO}$ in benene- $d_{6} .(*)$ indicates the presence of $\left[\mathrm{K}\left(18\right.\right.$-crown-6)][ $\left.\mathrm{L}^{\mathrm{tBu}} \mathrm{Ni}(\mathrm{S})\right],(\diamond)$ indicates the presence of $\left[\mathrm{L}^{\mathrm{tBu}} \mathrm{Ni}(\mathrm{NO})\right](2),(\square)$ indicates the presence of unidentified minor side products. 
X-ray Crystallography. Data for $\mathbf{1 - 3}$ were collected on a Bruker KAPPA APEX II diffractometer equipped with an APEX II CCD detector using a TRIUMPH monochromator with a Mo K $\alpha$ X-ray source $(\alpha=0.71073 \AA)$. The crystals were mounted on a cryoloop under Paratone-N oil, and all data were collected at 100(2) K using an Oxford nitrogen gas cryostream. Data were collected using $\omega$ scans with $0.5^{\circ}$ frame widths. Frame exposures of 15, 10, and 5 seconds were used for $\mathbf{1}, \mathbf{2}$, and $\mathbf{3}$, respectively. Data collection and cell parameter determination were conducted using the SMART program. ${ }^{5}$ Integration of the data frames and final cell parameter refinement were performed using SAINT software. ${ }^{6}$ Absorption correction of the data was carried out using the multi-scan method SADABS. ${ }^{7}$ Subsequent calculations were carried out using SHELXTL. ${ }^{8}$ Structure determination was done using direct or Patterson methods and difference Fourier techniques. All hydrogen atom positions were idealized, and rode on the atom of attachment. Structure solution, refinement, graphics, and creation of publication materials were performed using SHELXTL. ${ }^{8}$

In complex 1, two of the $\mathrm{C}_{6} \mathrm{H}_{6}$ solvate molecules exhibited some positional disorder; alternate positions were found for both molecules: one was refined in a 50:50 ratio, and the second was modelled in a 57:43 ratio, using the FVAR command in SHELXL. The C-C bonds in the $\mathrm{C}_{6} \mathrm{H}_{6}$ molecules were constrained to $1.4 \AA$ using the DFIX command. Hydrogen atoms were not added to disordered carbon atoms. Additionally, the $[\mathrm{SCO}]^{2-}$ ligand was found to be disordered over two orientations, which were related by a $C_{2}$ rotation about the Ni-K vector. These two orientations were modelled in a 70:30 ratio using the FVAR command in SHELXL. In complex 2, the O-atom in the NO ligand is disordered over two positions, which were modelled in a 50:50 ratio using the FVAR 
command in SHELXL. Additionally, the NO bond lengths were constrained using the SADI command in SHELXL. Further crystallographic details for complexes 1-3 can be found in Table S1.

Table S1. X-ray Crystallographic Data for complexes 1, 2, and 3.

\begin{tabular}{|c|c|c|c|}
\hline & $\mathbf{1} \cdot 2 \mathrm{C}_{6} \mathrm{H}_{6}$ & 2 & 3. $\mathrm{CH}_{2} \mathrm{Cl}_{2}$ \\
\hline empirical formula & $\begin{array}{c}\mathrm{C}_{48} \mathrm{H}_{77} \mathrm{KN}_{2} \mathrm{NiO}_{7} \mathrm{~S} \\
2\left(\mathrm{C}_{6} \mathrm{H}_{6}\right)\end{array}$ & $\mathrm{C}_{35} \mathrm{H}_{53} \mathrm{~N}_{3} \mathrm{NiO}$ & $\begin{array}{c}\mathrm{C}_{12} \mathrm{H}_{24} \mathrm{KNO}_{7} \mathrm{~S}_{2} \\
\left(\mathrm{CH}_{2} \mathrm{Cl}_{2}\right)\end{array}$ \\
\hline crystal habit, color & Plate, Orange & $\begin{array}{l}\text { Plate, Blue-Orange } \\
\text { dichroic }\end{array}$ & Plate, Orange \\
\hline crystal size (mm) & $0.15 \times 0.1 \times 0.05$ & $0.2 \times 0.15 \times 0.05$ & $0.5 \times 0.4 \times 0.1$ \\
\hline crystal system & Triclinic & Monoclinc & Monoclinc \\
\hline space group & $P-1$ & $C 2 / c$ & $P 21 / n$ \\
\hline volume $\left(\AA^{3}\right)$ & $3071.9(9)$ & $3414.4(4)$ & $2205.4(5)$ \\
\hline$a(\AA)$ & $12.668(2)$ & $16.832(1)$ & $9.477(1)$ \\
\hline$b(\AA)$ & $13.370(2)$ & $9.3700(6)$ & $14.048(2)$ \\
\hline$c(\AA)$ & $20.680(3)$ & $22.582(2)$ & 16.771(3) \\
\hline$\alpha(\mathrm{deg})$ & $80.951(4)$ & 90 & 90 \\
\hline$\beta(\operatorname{deg})$ & $88.335(4)$ & $106.526(5)$ & $98.978(4)$ \\
\hline$\gamma(\operatorname{deg})$ & $62.771(3)$ & 90 & 90 \\
\hline$Z$ & 2 & 4 & 4 \\
\hline $\begin{array}{l}\text { formula weight } \\
\text { ( } \mathrm{g} / \mathrm{mol})\end{array}$ & 1080.18 & 590.51 & 482.47 \\
\hline $\begin{array}{l}\text { density (calculated) } \\
\left(\mathrm{Mg} / \mathrm{m}^{3}\right)\end{array}$ & 1.158 & 1.149 & 1.453 \\
\hline $\begin{array}{l}\text { absorption coefficient } \\
\left(\mathrm{mm}^{-1}\right)\end{array}$ & 0.466 & 0.597 & 0.704 \\
\hline $\mathrm{F}_{000}$ & 1146 & 1280 & 1008 \\
\hline total no. reflections & 27019 & 12977 & 9506 \\
\hline unique reflections & 12508 & 4835 & 4564 \\
\hline$R_{\text {int }}$ & 0.0559 & 0.0574 & 0.0280 \\
\hline $\begin{array}{l}\text { final R indices (I } \\
>2 \sigma(\mathrm{I})]\end{array}$ & $\begin{array}{c}\mathrm{R}_{1}=0.0791 \\
\mathrm{wR}_{2}=0.2006\end{array}$ & $\begin{aligned} \mathrm{R}_{1} & =0.0513 \\
\mathrm{wR}_{2} & =0.1073\end{aligned}$ & $\begin{array}{c}\mathrm{R}_{1}=0.0343 \\
\mathrm{wR}_{2}=0.0676\end{array}$ \\
\hline $\begin{array}{l}\text { largest diff. peak and } \\
\text { hole }\left(\mathrm{e}^{-} \mathrm{A}^{-3}\right)\end{array}$ & 1.725 and -0.687 & 0.642 and -0.643 & 0.485 and -0.556 \\
\hline GOF & 1.038 & 1.035 & 1.016 \\
\hline
\end{tabular}




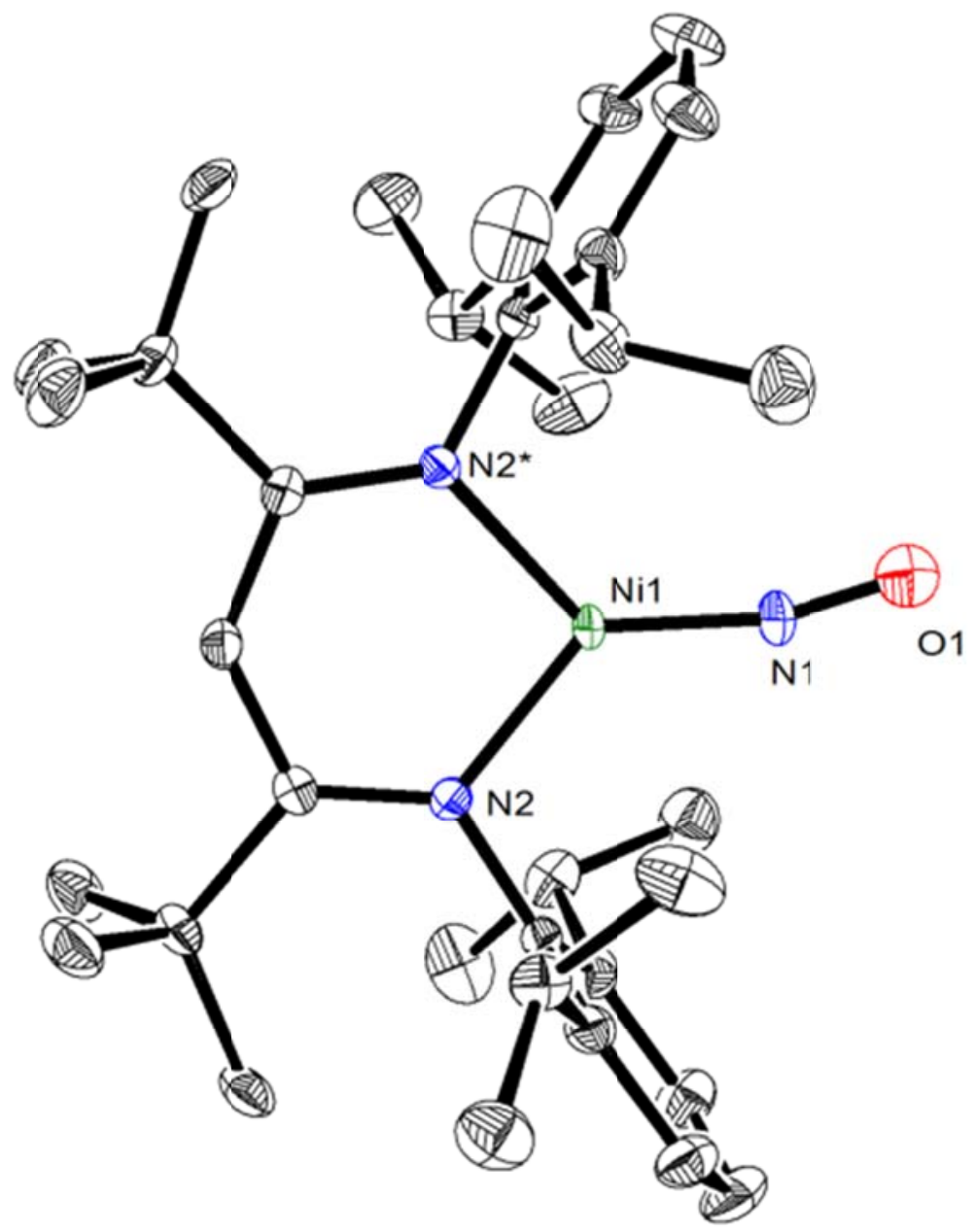

Figure S8. ORTEP drawing of $\left[\left(\mathrm{L}^{\mathrm{tBu}}\right) \mathrm{Ni}(\mathrm{NO})\right](2)$ shown with $50 \%$ thermal ellipsoids. Hydrogen atoms have been omitted for clarity. Selected metrical parameters: Ni1-N2

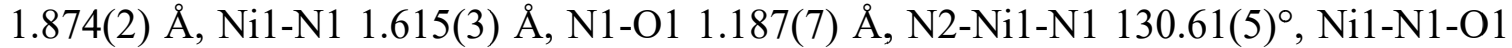
$164.5(3)^{\circ}$. 


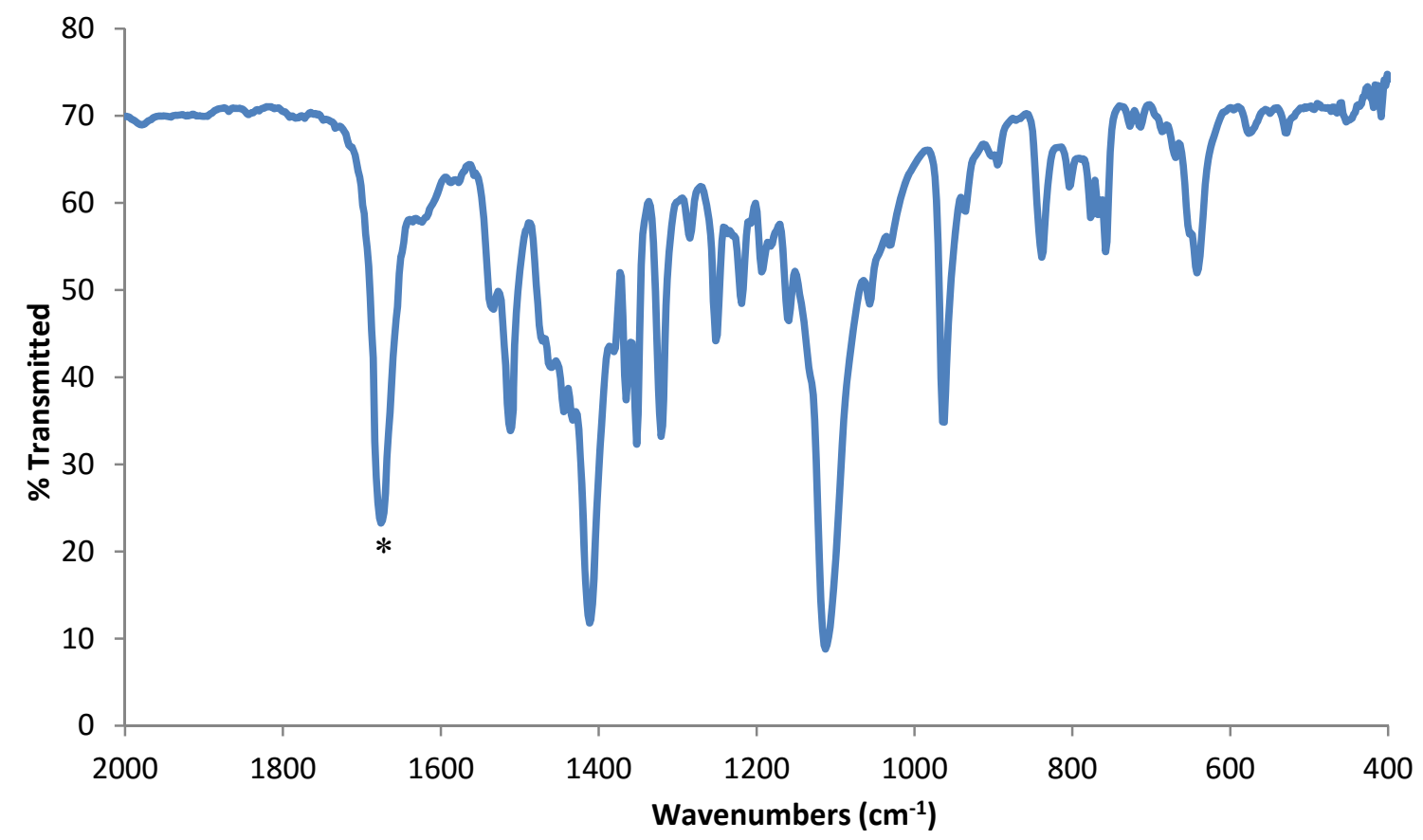

Figure S9. Partial IR spectrum of complex 1 (KBr pellet). (*) indicates the $v_{\mathrm{CO}}$ stretch $\left(1676 \mathrm{~cm}^{-1}\right)$.

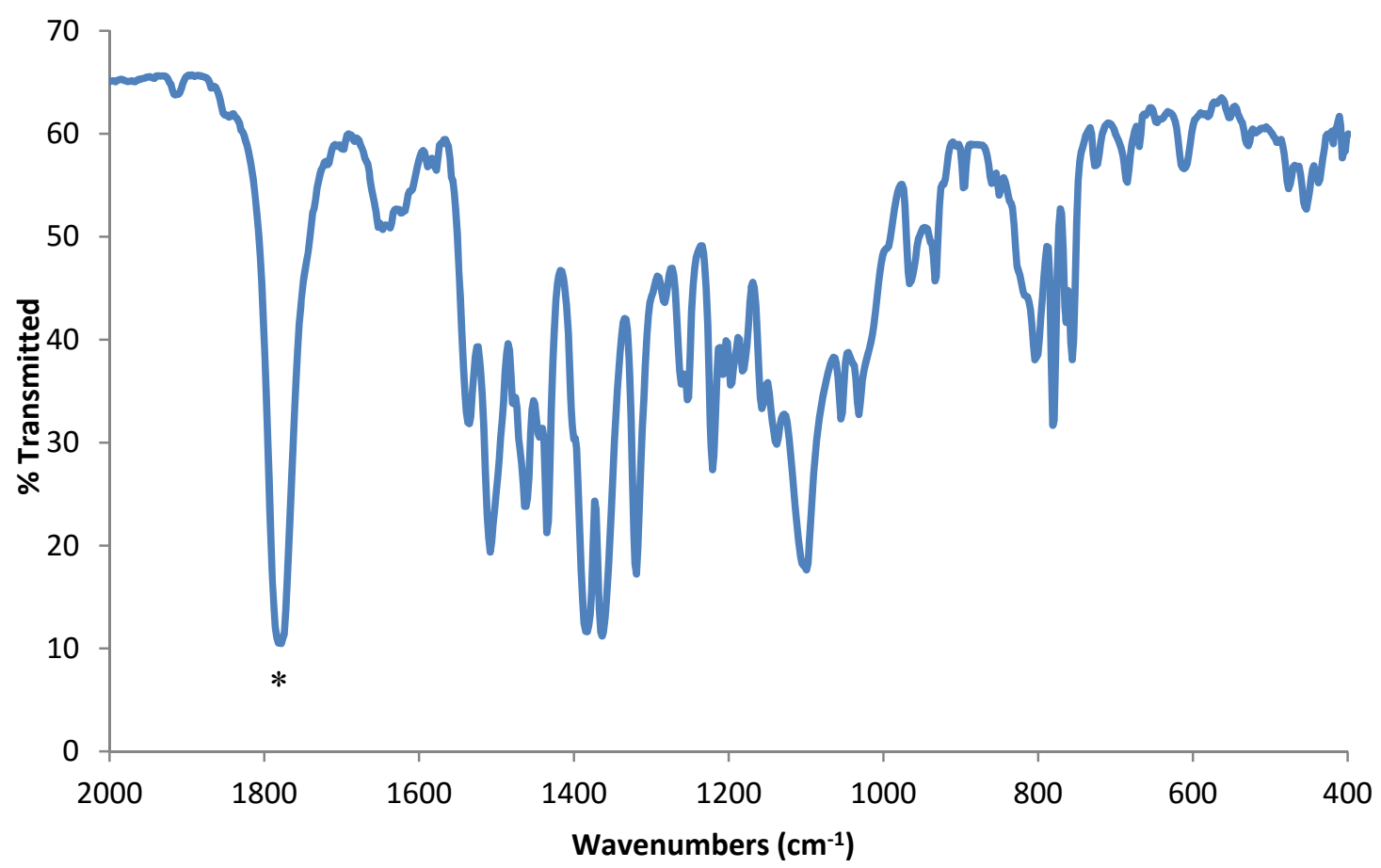

Figure S10. Partial IR spectrum of complex 2 (KBr pellet). $\left(^{*}\right)$ indicates the $v_{\mathrm{NO}}$ stretch $\left(1784 \mathrm{~cm}^{-1}\right)$. 


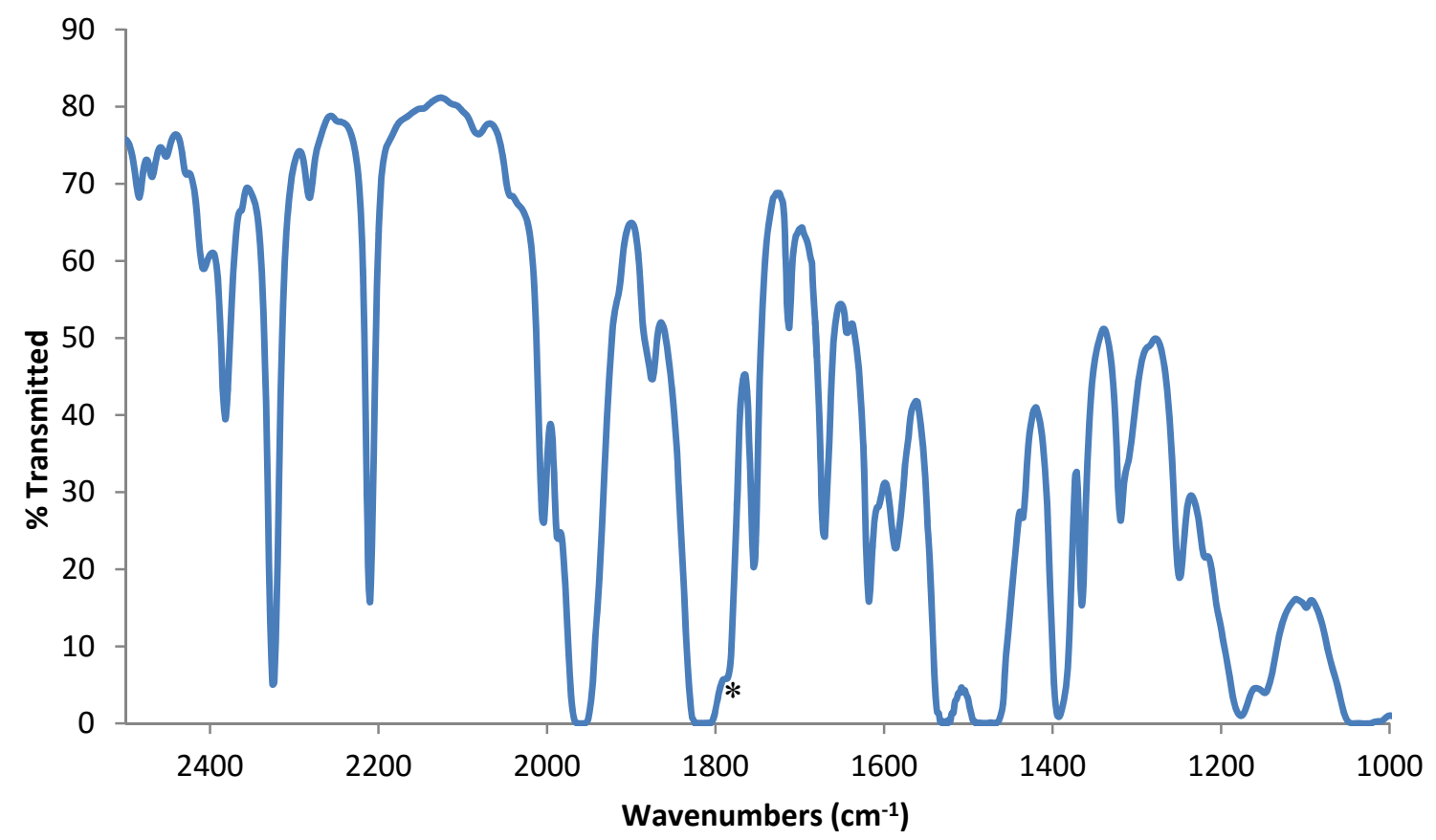

Figure S11. Partial solution IR spectrum of complex $2\left(\mathrm{C}_{6} \mathrm{H}_{6}, 25^{\circ} \mathrm{C}\right)$. (*) indicates the $v_{\mathrm{NO}} \operatorname{stretch}\left(1784 \mathrm{~cm}^{-1}\right)$.

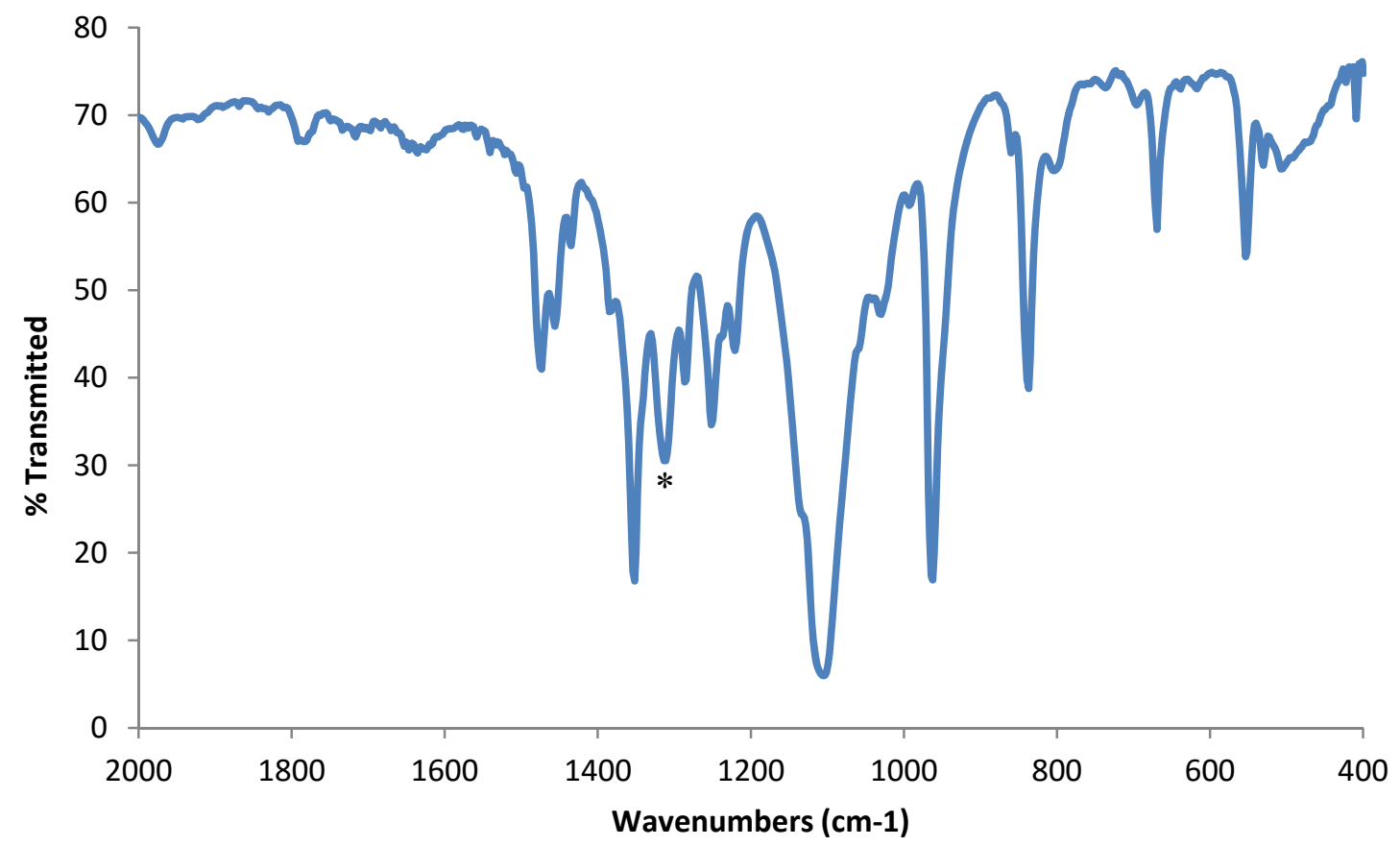

Figure S12. Partial IR spectrum of complex 3 (KBr pellet). $\left(^{*}\right)$ indicates the $v_{\mathrm{NO}}$ stretch $\left(1313 \mathrm{~cm}^{-1}\right)$. 


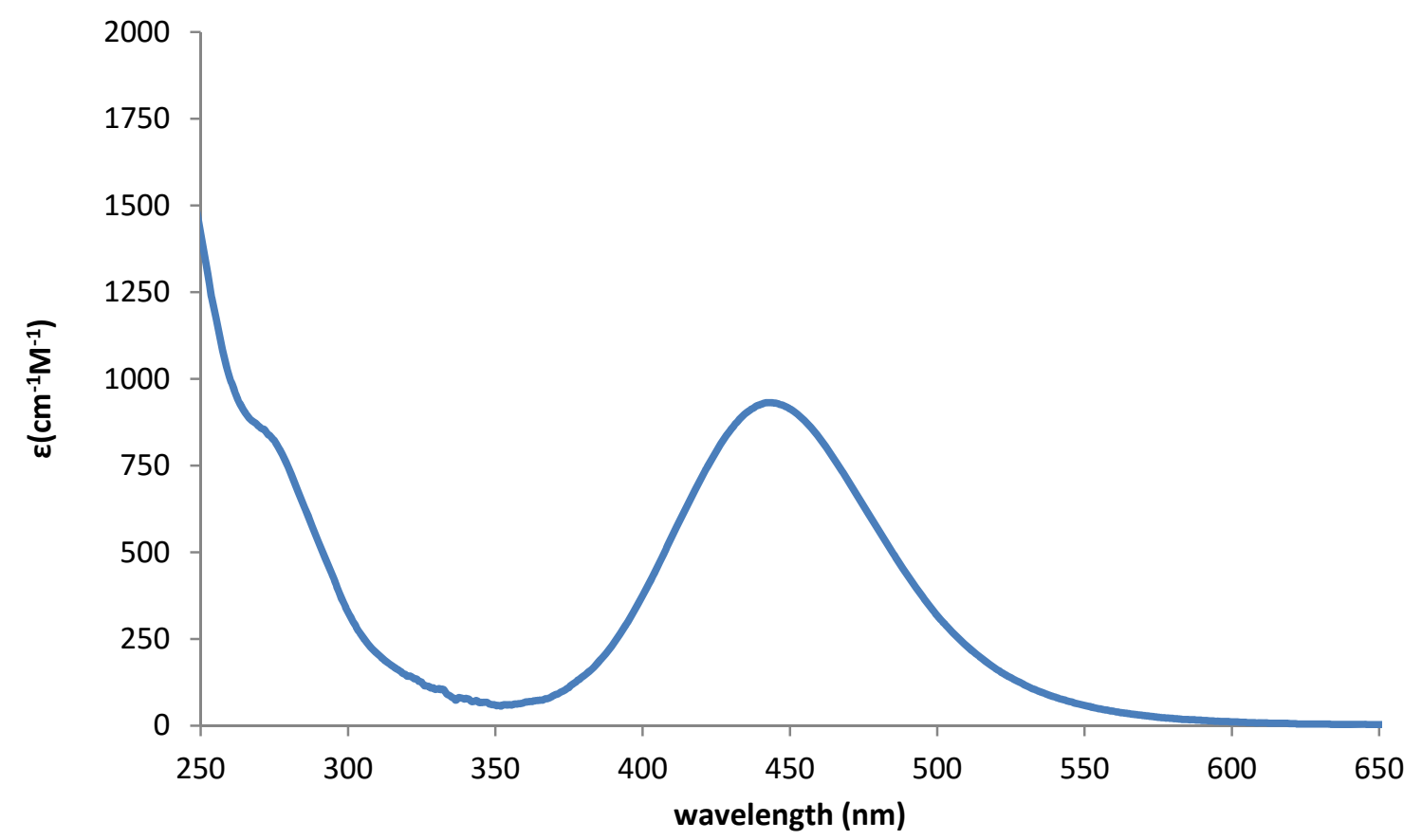

Figure S13. UV-vis spectrum of complex $3(1.0 \mathrm{mM}$ in $\mathrm{MeCN})$.

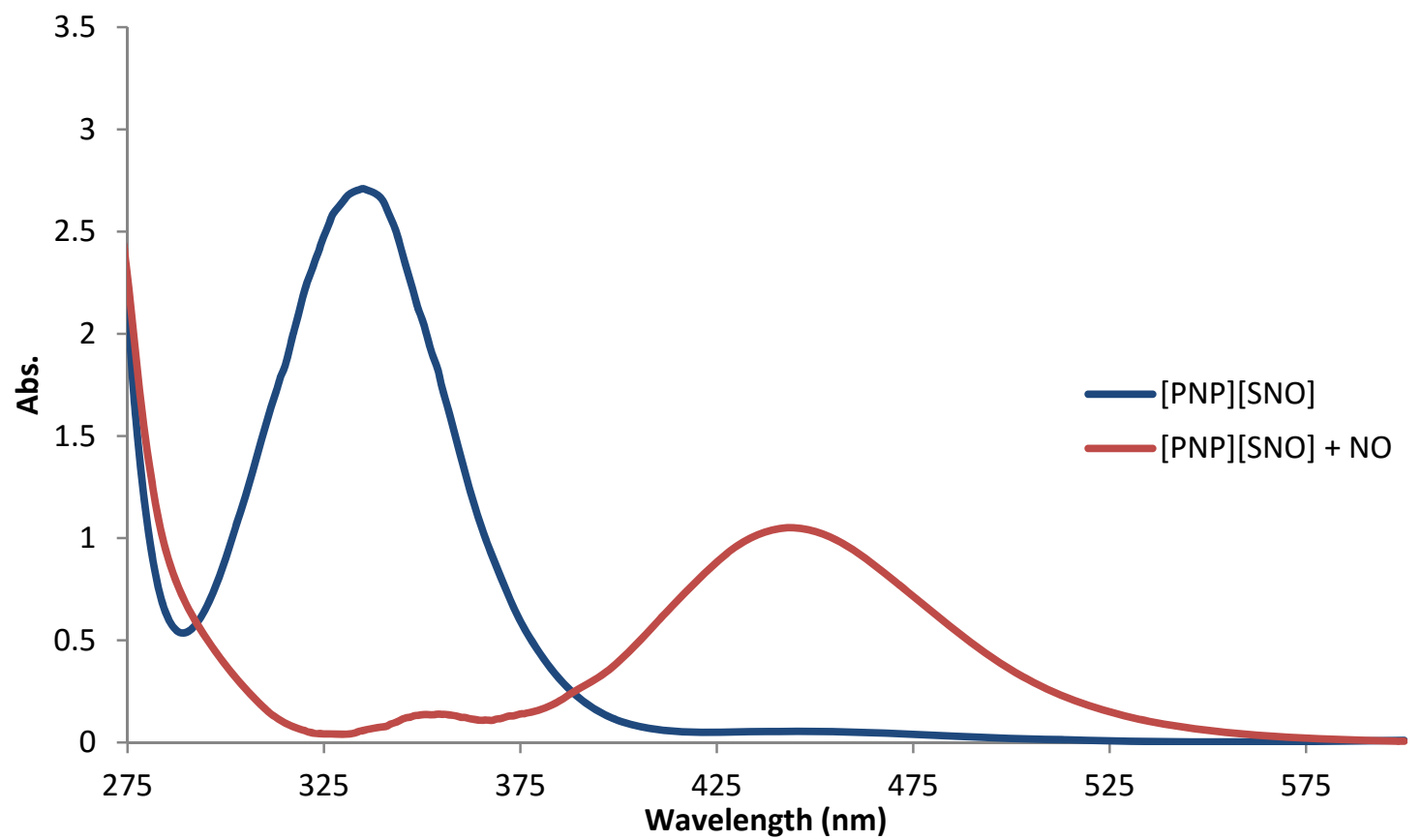

Figure S14. UV-vis spectrum of the reaction of $[\mathrm{PNP}][\mathrm{SNO}]$ with excess $\mathrm{NO}$ in $\mathrm{MeCN} .^{3}$ 


\section{References}

(1) Hartmann, N. J.; Wu, G.; Hayton, T. W. Angew. Chem. Int. Ed. 2015, 54, 14956.

(2) Martinsen, A.; Songstad, J. Acta Chem. Scand. A 1977, 31, 645.

(3) Seel, F.; Kuhn, R. G.; Simon, G.; Wagner, M.; Krebs, B.; Dartmann, M. Z. Naturforsch. B 1985, 40, 1607.

(4) Baccolini, G.; Boga, C.; Mazzacurati, M. J. Org. Chem. 2005, 70, 4774.

(5) SMART Apex II, Version 2.1; Bruker AXS Inc.: Madison, WI, 2005.

(6) SAINT Software User's Guide, Version 7.34a; Bruker AXS Inc.: Madison, WI, 2005.

(7) Sheldrick, G. M. SADABS, University of Gottingen, Germany: 2005.

(8) SHELXTL PC, Version 6.12; Bruker AXS Inc.: Madison, WI, 2005. 